\title{
THE SUPPORTING BEHAVIOUR OF GENERATIONS TOWARDS NON- PROFIT ORGANISATIONS IN GAUTENG
}

\author{
Laureane du Plessis: University of Johannesburg \\ Danie Petzer: University of Johannesburg
}

Purpose and objective: The purpose of this paper is to provide a better understanding of different generations' supporting behaviour towards non-profit organisations (NPOs). It more specifically focuses on uncovering the different methods with which the generations support NPOs; how frequently they support NPOs; the type of NPOs that they prefer supporting; and the reasons why they support NPOs.

Problem Investigated: Non-profit organisations (NPOs) are facing greater challenges than ever before. They have to compete with a growing number of other NPOs for donations and volunteers. Their traditional support from Baby Boomers is declining as this generation grows older and supports NPOs to a lesser extent than before. NPOs are therefore compelled to pay more attention to younger generations as a possible donor base and source for volunteers. It is therefore critical for an NPO that wishes to survive and prosper to understand the supporting behaviour of the different generations in order to successfully target them to grow the donor and volunteer base.

Methodology: A descriptive research design was followed. A self-administered questionnaire was fielded amongst a target population that included Baby Boomers, Generation $X$ and Generation $Y$ consumers residing in Gauteng who have supported an NPO in the previous year. Quota sampling was used to ensure that equal numbers of respondents from the different generations were included, while each quota was filled on the basis of convenience to collect 602 responses for analysis.

Findings: The results reveal significant associations between the different generations and different supporting behaviours. Significant differences were also uncovered between the different generations and the reasons for supporting NPOs. The paper reveals a number of marketing strategies NPOs could follow to encourage supporting behaviour from the different generations.

Value of the research: This research provides insights into the supporting behaviour of different generations towards NPOs and allows NPOs to develop more effective marketing strategies when targeting different generations.

Conclusion: Since the results reveal a number of associations between generations and particular supporting behaviours as well as similarities and differences between the generations and reasons for supporting NPOs, NPO marketers should take these into account when targeting the different generations for support.

Keywords: Non-profit organisation, supporting behaviour, Baby Boomers, Generation X, Generation Y

\section{INTRODUCTION}

Non-profit organisations (NPOs) often struggle to survive due to tight budgets, limited marketing skills, and a paucity of research to aid them in understanding their support base (Lamb, Hair, McDaniel, Boshoff \& Terblanche, 2008:421). This intensity of competition is in part due to the increasing number of NPOs that operates in South Africa. During 2010, approximately 71000 organisations were registered with the Department of Social Development, of which 20948 are registered in Gauteng (Department of Social Development, 2010). These organisations compete for the same donor and volunteer base and end up receiving a smaller "cut of the pie" (Ranganathan \& Henley, 2008:2).

Furthermore, individual factors such as the demographic, socio-economic and psychographic characteristics of donors affect the levels of donations made to NPOs. Age in particular is viewed as a critical demographic factor influencing how donors support NPOs. Consequently, donations to NPOs usually decline once donors reach the age of 65. NPOs therefore need to shift their focus from older individuals to the younger generations for donor support if they are to succeed (Blackwell, Miniard \& 


\section{L du Plessis \\ DJ Petzer}

\section{The supporting behaviour of generations towards non- profit organisations in Gauteng}

Engel, 2006:245; Lamb et al., 2008:421\&422; Schlegelmilch, Diamantopoulos \& Love, 1997:20\&24; Thornton, 2006:204). In order to attract younger generations and maintain existing relationships with older generations, it is necessary for NPOs to have a better understanding of their donors' supporting behaviour as this would enable them to develop more effective marketing campaigns (Nichols, 2004:167; Webb, Green \& Brashear, 2000:300).

This paper therefore aims at providing a better understanding of how the different generations currently support NPOs, and subsequently suggest strategies to successfully target younger generations to increase the donor and volunteer base.

\section{LITERATURE REVIEW}

\section{Non-profit organisations}

NPOs are defined as trusts, organisations, or voluntary associations of people that are established for a public purpose. Therefore, income and/or property generated are not distributed amongst members or office-bearers of the NPO, except as reasonable compensation for services rendered (Department of Social Development, 2008). NPOs strive to manage voluntary social actions by bringing people together to form mutually beneficial relationships with the purpose of producing goods and services that will benefit society (Clohesy, 2003:135). NPOs usually get involved with a number of activities in society including welfare and humanitarian causes, health care, land and housing, education and development, religion, cultural activities, conservation, environment and animal welfare, research and sporting activities (South African Revenue Service, 2007:53-58).

Interactions within the NPO environment are usually two-sided (Lamb et al., 2008:422). On the one hand, the NPO markets itself to donors and volunteers with the intention of generating support from them. On the other hand, support generated is allocated to the relevant beneficiaries (Briggs, Landry \& Wood, 2007:30; Lamb et al., 2008:422). For the purpose of this study, the focus falls on the first activity of attracting support. While a number of studies have been done on how NPOs can effectively obtain monetary contributions from donors and how NPOs can involve more volunteers (Briggs et al., 2007:30), little has been done to investigate how different generations support NPOs. Before addressing the different generations under study, it is necessary to investigate supporting behaviour.

\section{Supporting behaviour}

The ways in which individuals support NPOs may include donations of time, money, blood or goods (Briggs et al., 2007:30; Southern Africa Institute of Fundraising, 2009). While this is often referred to as helping behaviour (Briggs et al., 2007:30), for the purpose of this study, these charitable activities are collectively referred to as supporting behaviour. As such, NPOs usually target donors and volunteers with the intention to obtain support from them (Lamb et al., 2008:422). Donors are defined as individuals, corporations, foundations or groups that support NPOs by donating gifts that are valuable to them, such as money, goods or blood (Southern Africa Institute of Fundraising, 2009). Volunteers on the other hand, are defined as individuals who work for NPOs without receiving any compensation for the work done (Southern Africa Institute of Fundraising, 2009).

Individuals usually engage with NPOs on different levels of involvement. At a low-level involvement, individuals renew membership to a supporter's group, give small donations or sign a petition. On a moderate level, individuals tend to sign monthly debit order forms or volunteer time on a monthly basis (Hibbert \& Horne, 1996:6-8). High-level involvement involves donating a considerable amount of money or time to an NPO, sponsoring a child, or changing religion (Hibbert \& Horne, 1996:6-8).

People furthermore donate (money, goods or blood) for various reasons. People donate because they:

- feel strongly about the cause;

- want to give back to the community;

- want to give to others who are less fortunate; 
- $\quad$ are required to do so by their employer;

- feel better about themselves;

- react to the illness of a family member, friend or co-worker;

- feel it's the right thing to do;

- give out of habit;

- do so out of religious tradition (for example: tithing);

- are of the opinion that it enhances their social standing; and

- experience a reduced feeling of guilt (Andreasen \& Kotler, 2003:199\&200; Blackwell et al., 2006:306; Gladden, Mahony \& Apostolopoulou, 2005:19; Kottasz, 2004:11-13; Lemmens, Abraham, Ruiter, Veldhuizen, Dehing, Bos \& Schaalma, 2009:73-74; Riecken \& Yavas, 2005:577).

Donating money and goods is not the only way NPOs seek support. Volunteers donate their time and are crucial to the success of NPOs. They help to keep the NPOs' expenses down, and provide a platform for citizens to get involved with a cause that they care about (Briggs et al., 2007:28). Volunteers spontaneously choose the activities that they want to be part of, knowing that there is no financial gain involved (Andreasen \& Kotler, 2003:217-218). NPOs that are dependent on volunteers often struggle to find voluntary workers and cannot really pick and choose whom they take. As with their profit-driven counterparts, NPOs rely heavily on marketing and Human Resource (HR) management tools to recruit volunteers (Wilson \& Pimm, 1996:29).

Whilst there are specific reasons why people donate, there are also several reasons why people volunteer. These include:

- it allows them to help others;

- it helps people to help themselves by advancing their own job prospects and skills;

- it enhances peoples' relationships with their friends;

- it allows people to receive positive regard from others;

- it makes people feel better about themselves; and

- it allows people to escape boredom, personal problems and alienation (Andreasen \& Kotler, 2003:225; Tschirhart, Mesch, Perry, Miller \& Lee, 2001:426; Wilson \& Pimm, 1996:25-27\&30-31).

Riecken and Yavas (2005:574) furthermore profess that various demographic, socio-economic, and psychographic characteristics also influence whether and how much people donate. Donor behaviour is changing and the most important variables that play a role here include gender, age, family life cycle, household income, level of education, importance of religion and whether a person volunteers or not (Schlegelmilch et al., 1997:15). When considering age, it is evident that donations increase as donors become older, but tend to decline once donors reach the age of 65 (Schlegelmilch et al., 1997:20,24). It is therefore necessary to specifically uncover the role of age in the supporting behaviour of NPOs.

\section{Generations and their supporting behaviour}

Age is probably the most important segmentation base to use when dividing the target market into smaller, more homogeneous groups (Macchiette \& Roy, 2001:266). It also forms the foundation for the theory of how the generations affect marketing, as it indicates the unique norms and values of the different generations (Andreasen \& Kotler, 2003:149; Macchiette \& Roy, 2001:266). Understanding the different generations, allows marketers to predict the types of products and services that will be bought and consumed by each (Blackwell et al., 2006:245).

Different authors use different names and different periods to describe each generation. However, in the end generation theory should be viewed as a form of generalisation, without sharp and fixed boundaries between the different generations (Codrington \& Grant-Marshall, 2005:18; Hawkins \& Mothersbaugh, 2010:125). While six generations have been identified in recent history, for the purposes of the study, the focus falls on Baby Boomers, Generation X and Generation $Y$ as defined by Hawkins and Mothersbaugh (2010:125-135). 
Baby Boomers were born after the Second World War between 1946 and 1964, and they represent the largest generation in American history (Bakewell \& Mitchell 2003:99; Hawkins \& Mothersbaugh, 2010:127128). They have higher levels of education than the preceding generations, causing them to have higher levels of income (Hawkins \& Mothersbaugh, 2010:128). Baby Boomers are optimistic, self-centred, confident, idealistic, and driven (Blackwell et al., 2006:443; Codrington \& Grant-Marshall, 2005:43; Hawkins \& Mothersbaugh, 2010:128). They tend to have dual-career households, but are entering the "empty nest" phase of the household life cycle, which leaves them with more time and money to spend on themselves (Hawkins \& Mothersbaugh, 2010:128). With retirement fast approaching, the Baby Boomers are turning to products and services that can help them look and feel young again (Reisenwitz \& lyer, 2009:91).

From an NPO perspective, Baby Boomers tend to support causes that they are associated with: their churches, the educational institutions that their children are attending, the arts that they are interested in, and the health and medical organisations that look after them (Nichols, 2004:165). Baby Boomers are a good potential target market for bequests (Magson \& Routley, 2009:333-335).

Generation $X$ refers to people who were born between 1965 and 1976 (Bakewell \& Mitchell, 2003:99; Hawkins \& Mothersbaugh, 2010:129\&131). With an increasing number of Generation X members attending colleges and universities, they are becoming better educated than Baby Boomers (Hawkins \& Mothersbaugh, 2010:130). Generation X members want to be recognised as individuals with unique needs and wants (Codrington \& Grant-Marshall, 2005:50\&52). They like adapting to change and taking risks, and believe in getting things done (Codrington \& Grant-Marshall, 2005:47\&50). They are furthermore regarded as pessimistic, cynical, materialistic, impatient, demanding, uppity and disrespectful (Blackwell et al., 2006:444; Hawkins \& Mothersbaugh, 2010:131; Hoyer \& Maclnnis, 2010:305). Generation $X$ individuals usually left home later than previous generations; they delayed marriage and waited a while before having children (Blackwell et al., 2006:246, 444; Hoyer \& Maclnnis, 2010:305). They strive for a balance between work and quality of life, and place high value on relationships (Blackwell et al., 2006:444; Hawkins \& Mothersbaugh, 2010:130; Hoyer \& Maclnnis, 2010:305).

In terms of the non-profit environment, members of Generation $X$ take time out to initiate relationships with NPOs and often research various causes before contacting them (Nichols, 2004:167). They tend to prefer supporting causes that centre around the broader community and that address social concerns - including famine, homelessness, violence, care for the environment and economic aid for third-world countries (Codrington \& Grant-Marshall 2005:52; Nichols, 2004:165). Compared to Baby Boomers, the Generation $X$ group prefers donating time rather than money, and they are therefore a good market to approach for volunteering (Burns, Reid, Toncar, Anderson \& Wells, 2008:100; Reisenwitz \& lyer, 2009:100-101).

Generation $Y$ represents people who were born between 1977 and 1994 (Hawkins \& Mothersbaugh, 2010:132-133). While the Generation $Y$ teens are at school, the late teens and "twenty-somethings" are either part-time or full-time students at a tertiary institution or entering the world of work (Hawkins \& Mothersbaugh, 2010:133). With higher levels of education, higher levels of income can be expected from this generation (Hawkins \& Mothersbaugh, 2010:133). The members of Generation $Y$ are presentable, confident, self-reliant, emotionally and intellectually expressive, innovative, curious and very optimistic (Burns et al., 2008:103; Mi \& Nesta, 2006:417; Reisenwitz \& lyer, 2009:92). They are open-minded, know what they want out of life, and are willing to figure things out for themselves (Codrington \& Grant-Marshall, 2005:56-63; Hawkins \& Mothersbaugh, 2010:133; Mi \& Nesta, 2006:416). The members of Generation $Y$ are caring individuals who show great concern for the community and the environment in which they live (Codrington \& Grant-Marshall, 2005:63). As a result, members of Generation Y are very active in their communities (Burns et al., 2008:100). As with Generation X, this generation prefers supporting NPOs that focus on the broader community (Nichols, 2004:165). Generation Y members get involved in society through recycling, volunteering, educating friends and family about social and environmental causes, and donating money (Cone Incorporated, 2006:3). This generation is keen to support cause initiatives, and, like Generation X, takes time out to initiate relationships with NPOs (Nichols, 2004:167). 
In terms of volunteering, Generation $\mathrm{Y}$ shows an even greater tendency to get involved with volunteering than the other generations (Burns et al., 2008:103). A study conducted by Reisenwitz and lyer (2009:100) states that Generation $Y$ is more likely to get involved through volunteering than donating money, and NPOs can expect this tendency to continue. Getting involved in the community is important to younger people, and they see it as part of their work-life balance (Reisenwitz \& lyer, 2009:93).

Based on the literature presented above, the following alternative hypotheses are formulated for this study:

- $\mathrm{H}_{1}$ : There is an association between the different generations and their preferred methods of supporting NPOs.

- $\mathrm{H}_{2}$ : There is an association between the different generations and the frequency with which they support NPOs.

- $\mathrm{H}_{3}$ : There is an association between the different generations and the type of NPOs that they prefer supporting.

- $\mathrm{H}_{4}$ : There is a significant difference between the levels of agreement that the different generations assign to their reasons for supporting NPOs.

\section{PROBLEM STATEMENT, PURPOSE AND OBJECTIVES}

Non-profit organisations (NPOs) are facing greater challenges than ever before. They have to compete with a growing number of other NPOs for donations and volunteers (Ranganathan \& Henley, 2008:2). NPOs are also compelled to pay more attention to younger generations (Generation X and Generation Y) as a donor base and source for volunteers. This is in part due to the fact that their traditional donor and volunteer base, namely Baby Boomers' support is declining as this generation grows older (Reisenwitz \& lyer, 2009:91). As a result, NPOs need to start focusing on the younger generations (Generation $X$ and Generation Y) for support and accordingly develop strategies to attract these younger donors (Schlegelmilch et al., 1997:24). But doing so is not an easy task, as there is limited research available on how the different generations support NPOs. Consequently, the purpose of this paper is to provide a better understanding of how the different generations currently support NPOs.

Thus, the primary objective of this study is to investigate how Baby Boomers, Generation $\mathrm{X}$ and Generation Y individuals currently support NPOs in Gauteng, South Africa.

In order to attain the primary objective, the following secondary objectives were formulated:

- Uncover the different methods in which the different generations support NPOs.

- Determine how frequently the different generations support NPOs.

- Identify the type of NPOs that the different generations prefer supporting.

- Establish the reasons why the different generations support NPOs.

\section{METHODOLOGY}

The study is quantitative in nature and a descriptive research design was followed to collect the data. In order to inform the questionnaire design process, five informal expert surveys were conducted with the marketing or fundraising managers of NPOs situated in Gauteng. A self-administered questionnaire was subsequently designed and pretested. By doing this, face and content validity of the questionnaire were established. In other words; does the questionnaire seem to measure what the researchers intend it to measure, and does it include the right questions to obtain the necessary information?

The target population included all Baby Boomers (i.e. individuals born between 1946 and 1964), Generation X (i.e. individuals born between 1965 and 1976), and Generation Y members (i.e. individuals born between 1977 and 1994) residing in Gauteng, who had supported an NPO in the previous year and who were representative of the four major racial groups in South Africa (i.e. Black, Coloured, Indian and 
White). Due to the absence of a sampling frame, the researcher had to provide direction in terms of who qualified to participate in the study. A sample size of 200 respondents per generation was proposed. The researchers made use of trained fieldworkers to select respondents and field the questionnaire. Personal interviewing, in the form of in-home and intercept interviewing was used to obtain the necessary data from respondents living in Gauteng. Non-probability sampling was employed to select the sample. Quota sampling was used to ensure respondents from each generation were included, while convenience sampling was used to fill each quota. In the end, the researchers had 602 useable questionnaires.

The questionnaire was designed and pretested amongst the experts who participated in the surveys, as well as amongst a representative sample of 30 respondents. The questionnaire consisted of six sections, but for the purpose of this paper only the first three sections were considered. The first section of the questionnaire included two screening questions to determine whether the respondents qualified to partake in the survey - prospective respondents were asked whether they had donated in the past year and whether they fell within the relevant age brackets. Subsequently, the questionnaire included a section to determine the demographic profile of respondents, and another section investigated the respondents' current supporting behaviour.

Predictive Analysis Software Statistics package (PASW version 18) was used for data analysis purposes. Descriptive analysis was conducted to describe the relevant variables in terms of counts, frequencies, means, standard deviations, as well as top box and low box scores. In terms of hypotheses testing, parametric tests were used since the sample size was large enough $(n=602)$ and the distribution of results for the dependent variables subjected to the testing all fell within the acceptable limits of normality. The Pearson chi-square test of independence was used to measure whether there is an association between two variables, and the one-way ANOVA test was used to determine whether significant differences exist between the three generational cohorts (Malhotra, 2007:442, 505). The researchers relied on a $95 \%$ confidence level. A subsequent $5 \%$ level of significance or $p$-value of 0.05 or less is thus indicative of a significant association between variables, or a significant difference between at least two of the generations with regard to the particular variable tested. Once significance has been established, Cramer's $V$ measure of association can be used to indicate the strength of the association and the posthoc tests, Scheffe and Dunnett's T3 are used to determine the generations between which significant differences exist. Scheffe is suitable when equal variances can be assumed, and Dunnett's T3 when equal variances between the groups cannot be assumed. The homogeneity of variance test indicates which post-hoc test to use (Eiselen, Uys \& Potgieter, 2007:121).

\section{ANALYSIS AND INTERPRETATION OF FINDINGS}

\section{Sample profile}

Although a sample size of 200 respondents per generation was proposed, 181 Baby Boomers (30.1\%), 183 Generation X (30.4\%) and 238 Generation Y (39.5\%) respondents participated in the study, leading to a total of 602 useable questionnaires.

\section{Current supporting behaviour}

This section provides an overview of the different means by which respondents have supported NPOs in the past year, how frequently they have supported NPOs in the past year, and in what ways the different generations are involved and the type of NPOs (compiled from the classification provided by the South African Revenue Services (South African Revenue Service, 2007:53-58) each generation prefers supporting. 
Table 1: Current supporting behaviour of respondents 1

\begin{tabular}{|c|c|c|}
\hline Method of support for NPOs & $\mathbf{N}$ & $\%$ \\
\hline Donated money & 420 & 69.8 \\
\hline Donated goods & 401 & 66.6 \\
\hline Donated blood & 104 & 17.3 \\
\hline Volunteer work & 219 & 36.4 \\
\hline Other & 11 & 1.8 \\
\hline Frequency of support for NPOs & $\mathbf{N}$ & $\%$ \\
\hline Once a week & 89 & 14.8 \\
\hline Twice a month & 46 & 7.6 \\
\hline Once a month & 256 & 42.5 \\
\hline Every second month & 111 & 18.4 \\
\hline Twice a year & 218 & 36.2 \\
\hline Once a year & 253 & 42.0 \\
\hline Level of involvement with NPOs & $\mathbf{N}$ & $\%$ \\
\hline I am involved on a low level & 398 & 68.6 \\
\hline I am involved on a moderate level & 138 & 23.8 \\
\hline I am involved on a high level & 44 & 7.6 \\
\hline Similar/different NPOs & $\mathbf{N}$ & $\%$ \\
\hline Supporting the same NPO/s every time & 229 & 40.0 \\
\hline Supporting different NPO/s every time & 130 & 22.7 \\
\hline $\begin{array}{l}\text { Sometimes supporting the same NPO/s and sometimes supporting different } \\
\text { NPO/s }\end{array}$ & 213 & 37.2 \\
\hline Type of NPO/s supported & $\mathbf{N}$ & $\%$ \\
\hline Arts and culture & 31 & 5.1 \\
\hline Caring for adults & 149 & 24.8 \\
\hline Caring for animals & 119 & 19.8 \\
\hline Caring for children & 318 & 52.8 \\
\hline Disaster management & 30 & 5.0 \\
\hline Education and development & 97 & 16.1 \\
\hline Environment \& conservation & 37 & 6.1 \\
\hline Foundations & 124 & 20.6 \\
\hline Health care & 185 & 30.7 \\
\hline Land and housing & 11 & 1.8 \\
\hline Poverty relief & 108 & 17.9 \\
\hline Religious organisations & 289 & 48.0 \\
\hline Research organisations & 13 & 2.2 \\
\hline Sport and recreation & 52 & 8.6 \\
\hline Other: & 6 & 1.0 \\
\hline
\end{tabular}

The majority of the respondents prefer donating money $(69.8 \%)$, followed by those donating goods $(66.6 \%)$ and doing volunteer work $(36.4 \%)$. The respondents are more inclined to support NPOs on a monthly basis $(42.5 \%)$, followed by a tendency to support NPOs on an annual (42.0\%) or bi-annual basis $(36.2 \%)$. The majority of respondents tend to get involved with NPOs at a low level $(68.6 \%)$, while $23.8 \%$ of respondents are involved at a moderate level and $7.6 \%$ at a high level. The respondents indicated that they prefer supporting the same NPOs every time (40.0\%), while $37.2 \%$ sometimes support one NPO and sometimes support other NPOs. Most respondents provide support in one way or another to NPOs that care for children (52.8\%), followed by $48 \%$ who support religious organisations, and $30.7 \%$ who support health care organisations. The NPOs that received lower levels of support in the previous year were those involved in arts and culture (5.1\%), research (2.2\%), and land and housing organisations $(1.8 \%)$. 


\section{Reasons for supporting NPOs}

A number of possible reasons for supporting NPOs were stated and respondents were asked to indicate on a five-point Likert scale, where one is 'strongly disagree' and five is 'strongly agree', the extent to which they agreed with each one of the reasons. The results are summarised in Table 2.

\section{Table 2: Reasons for supporting NPOs 2}

\begin{tabular}{|l|l|l|l|}
\hline Reasons & $\mathbf{N}$ & Mean & $\begin{array}{l}\text { Standard } \\
\text { deviation }\end{array}$ \\
\hline It enables me to build contacts (i.e. networking) & 591 & 2.54 & 1.431 \\
\hline It helps me to develop new skills & 588 & 2.85 & 1.369 \\
\hline $\begin{array}{l}\text { It helps me escape from personal problems (for example: } \\
\text { boredom/loneliness) }\end{array}$ & 584 & 2.21 & 1.357 \\
\hline It makes me feel better about myself & 590 & 3.73 & 1.258 \\
\hline I feel strongly about the cause & 590 & 4.34 & 0.832 \\
\hline I like giving something back to the community & 595 & 4.36 & 0.842 \\
\hline I like helping people who are less fortunate & 588 & 4.41 & 0.796 \\
\hline Due to the illness of a family member, friend or co-worker & 585 & 2.64 & 1.473 \\
\hline I am interested in the activity & 583 & 3.73 & 1.149 \\
\hline It's the right thing to do & 594 & 4.26 & 0.993 \\
\hline It enables me to meet new people and establish friendships & 595 & 3.07 & 1.397 \\
\hline $\begin{array}{l}\text { It is part of my organisation's corporate social responsibility } \\
\text { initiative }\end{array}$ & 586 & 2.66 & 1.406 \\
\hline Religious tradition (for example: tithing - giving one tenth) & 593 & 3.19 & 1.556 \\
\hline To obtain a tax benefit & 589 & 1.53 & 1.014 \\
\hline To be recognised by others & 589 & 1.67 & 1.150 \\
\hline To enhance my social standing & 587 & 1.88 & 1.258 \\
\hline To remain active and involved & 588 & 3.37 & 1.290 \\
\hline $\begin{array}{l}\text { I want to assist in uplifting previously disadvantaged } \\
\text { communities }\end{array}$ & 589 & 3.90 & 1.153 \\
\hline I feel pressurised to support NPOs & 588 & 1.74 & 1.183 \\
\hline Other & 61 & 2.72 & 1.685 \\
\hline
\end{tabular}

Respondents exhibited the strongest levels of agreement with the statements 'I like helping people who are less fortunate' (mean $=4.41$ ), 'I like giving something back to the community' (mean $=4.36$ ) and 'I feel strongly about the cause' (mean $=4.34$ ). Statements with the lowest level of agreement include 'I feel pressurised to support NPOs' (mean $=1.74$ ), 'To be recognised by others' (mean $=1.67$ ) and 'To obtain a tax benefit' $($ mean $=1.53)$.

\section{Hypothesis testing}

This section provides the findings with regard to the four hypotheses formulated for this study.

\section{Hypothesis 1}

The first hypothesis focuses on whether associations are evident between the three generations and their preferred methods of support, namely donating money, donating goods, donating blood and volunteering. The cross-tabulations are presented in Tables 3, 4 and 5 respectively, and subsequently significant associations between the different generations and particular methods of support are indicated. For donating goods, significant associations between this method and the different generations could not be uncovered and a cross-tabulation is therefore not presented. 
Table 3: Money donations by the different generations

\begin{tabular}{|c|c|c|c|c|}
\hline & \multicolumn{2}{|c|}{ Donated money } & \multirow{2}{*}{ Total } \\
\hline & & No & Yes & \\
\hline \multirow{2}{*}{ Generation Y } & Count & 87 & 151 & 238 \\
\hline & $\%$ within To which generation do you belong? & $36.6 \%$ & $63.4 \%$ & $100 \%$ \\
\hline \multirow{2}{*}{ Generation X } & Count & 42 & 141 & 183 \\
\hline & $\%$ within To which generation do you belong? & $23.0 \%$ & $77.0 \%$ & $100 \%$ \\
\hline \multirow{2}{*}{ Baby Boomers } & Count & 53 & 128 & 181 \\
\hline & $\%$ within To which generation do you belong? & $29.3 \%$ & $70.7 \%$ & $100 \%$ \\
\hline \multirow[b]{2}{*}{ TOTAL } & Count & 182 & 420 & 602 \\
\hline & $\begin{array}{l}\% \text { within To which generation do you } \\
\text { belong? }\end{array}$ & $30.2 \%$ & $69.8 \%$ & $100 \%$ \\
\hline
\end{tabular}

The results of the Pearson chi-square test of independence indicate that there is a significant association, $\left(x^{2}(1, n=602)=9.188\right.$; small effect; Cramer's $V=0.124 ; p$-value $\left.=0.010\right)$ between the generations and donating money to an NPO. Generation $X$ is significantly more likely to donate money to NPOs than Generation Y or Baby Boomers.

Table 4: Blood donations by different generations

\begin{tabular}{|c|c|c|c|c|}
\hline & \multicolumn{2}{|c|}{ Donated blood } & \multirow{2}{*}{ Total } \\
\hline & & No & Yes & \\
\hline \multirow{2}{*}{ Generation Y } & Count & 187 & 51 & 238 \\
\hline & $\%$ within To which generation do you belong? & $78.6 \%$ & $21.4 \%$ & $100 \%$ \\
\hline \multirow{2}{*}{ Generation X } & Count & 147 & 36 & 183 \\
\hline & $\%$ within To which generation do you belong? & $80.3 \%$ & $19.7 \%$ & $100 \%$ \\
\hline \multirow{2}{*}{ Baby Boomers } & Count & 164 & 17 & 181 \\
\hline & $\%$ within To which generation do you belong? & $90.6 \%$ & $9.4 \%$ & $100 \%$ \\
\hline \multirow[b]{2}{*}{ TOTAL } & Count & 498 & 104 & 602 \\
\hline & $\begin{array}{l}\text { \% within To which generation do you } \\
\text { belong? }\end{array}$ & $82.7 \%$ & $17.3 \%$ & $100 \%$ \\
\hline
\end{tabular}

There is an association $\left(x^{2}(1, n=602)=11.479\right.$; small effect; Cramer's $V=0.138 ; p$-value $\left.=0.003\right)$ between the generations and donating blood. Generation $Y$ is more likely to donate blood than Generation $\mathrm{X}$ or Baby Boomers.

Table 5: Volunteering by different generations

\begin{tabular}{|c|c|c|c|c|}
\hline & & \multicolumn{2}{|c|}{ Done volunteer work } & \multirow{2}{*}{ Total } \\
\hline & & No & Yes & \\
\hline \multirow{2}{*}{ Generation Y } & Count & 129 & 109 & 238 \\
\hline & $\%$ within To which generation do you belong? & $54.2 \%$ & $45.8 \%$ & $100 \%$ \\
\hline \multirow{2}{*}{ Generation X } & Count & 122 & 61 & 183 \\
\hline & $\%$ within To which generation do you belong? & $66.7 \%$ & $33.3 \%$ & $100 \%$ \\
\hline \multirow{2}{*}{ Baby Boomers } & Count & 132 & 49 & 181 \\
\hline & $\%$ within To which generation do you belong? & $72.9 \%$ & $27.1 \%$ & $100 \%$ \\
\hline \multirow[b]{2}{*}{ TOTAL } & Count & 383 & 219 & 602 \\
\hline & $\begin{array}{l}\% \text { within To which generation do you } \\
\text { belong? }\end{array}$ & $63.6 \%$ & $36.4 \%$ & $100 \%$ \\
\hline
\end{tabular}


There is an association $\left(\mathrm{x}^{2}(1, \mathrm{n}=602)=16.631\right.$; small effect; Cramer's $\mathrm{V}=0.166$; $\mathrm{p}$-value $\left.=0.000\right)$ between the generations and doing volunteer work. Generation $Y$ is more likely to do volunteer work than Generation X or Baby Boomers.

Based on these results, Hypothesis 1 is partially supported, since there are associations between Generation X and supporting NPOs by donating money, as well as between Generation $Y$ and donating blood and Generation Y and supporting NPOs by doing volunteer work.

\section{Hypothesis 2}

Hypothesis 2 focuses on whether there are significant associations between the different generations and the frequency with which they support NPOs. Tables 6 and 7 contain the relevant cross tabulations followed by a discussion of the significant associations that could be uncovered.

Table 6: Generations supporting NPOs once a week

\begin{tabular}{|c|c|c|c|c|}
\hline & \multicolumn{2}{|c|}{$\begin{array}{l}\text { Supported once a } \\
\text { week }\end{array}$} & \multirow[t]{2}{*}{ Total } \\
\hline & & No & Yes & \\
\hline \multirow{2}{*}{ Generation Y } & Count & 184 & 54 & 238 \\
\hline & $\%$ within To which generation do you belong? & $77.3 \%$ & $22.7 \%$ & $100 \%$ \\
\hline \multirow{2}{*}{ Generation X } & Count & 166 & 17 & 183 \\
\hline & $\%$ within To which generation do you belong? & $90.7 \%$ & $9.3 \%$ & $100 \%$ \\
\hline \multirow{2}{*}{ Baby Boomers } & Count & 163 & 18 & 181 \\
\hline & $\%$ within To which generation do you belong? & $90.1 \%$ & $9.9 \%$ & $100 \%$ \\
\hline \multirow[b]{2}{*}{ TOTAL } & Count & 513 & 89 & 602 \\
\hline & $\begin{array}{l}\text { \% within To which generation do you } \\
\text { belong? }\end{array}$ & $85.2 \%$ & $14.8 \%$ & $100 \%$ \\
\hline
\end{tabular}

The results of the Pearson chi-square test of independence indicate an association $\left(x^{2}(1, n=602)=\right.$ 19.555; small effect; Cramer's $V=0.180 ; p$-value $=0.000$ ) between the generations and supporting NPOs once a week. Generation $Y$ is more likely to support NPOs once a week than Generation X and Baby Boomers.

Table 7: Generations supporting NPOs once a month

\begin{tabular}{|c|c|c|c|c|}
\hline & & NO & res & \\
\hline \multirow{2}{*}{ Generation Y } & Count & 152 & 86 & 238 \\
\hline & $\%$ within To which generation do you belong? & $63.9 \%$ & $36.1 \%$ & $100 \%$ \\
\hline \multirow{2}{*}{ Generation X } & Count & 100 & 83 & 183 \\
\hline & $\%$ within To which generation do you belong? & $54.6 \%$ & $45.4 \%$ & $100 \%$ \\
\hline \multirow{2}{*}{ Baby Boomers } & Count & 94 & 87 & 181 \\
\hline & $\%$ within To which generation do you belong? & $51.9 \%$ & $48.1 \%$ & $100 \%$ \\
\hline \multirow[b]{2}{*}{ TOTAL } & Count & 346 & 256 & 602 \\
\hline & $\begin{array}{l}\% \text { within To which generation do you } \\
\text { belong? }\end{array}$ & $57.5 \%$ & $42.5 \%$ & $100 \%$ \\
\hline
\end{tabular}

The results of the Pearson chi-square test of independence indicate an association $\left(x^{2}(1, n=602)=\right.$ 6.850; small effect; Cramer's $V=0.107 ; p$-value $=0.033$ ) between the generations and supporting NPOs once a month. Baby Boomers are more likely to support NPOs once a month than Generation $Y$ and Generation X. 
Based on the results presented above. Hypothesis 2 is partially supported since there are associations between Generation $Y$ and supporting NPOs once a week, and between the Baby Boomers and supporting NPOs once a month.

\section{Hypothesis 3}

Hypothesis 3 aims at determining whether significant associations exist between the different generations and the types of NPOs that they prefer supporting. The Pearson chi-square test of independence was used to test this hypothesis and a number of associations between the generations are evident. The cross tabulations pertaining to the associations are illustrated in Tables 8, 9 and 10.

Table 8: Generations supporting disaster management organisations

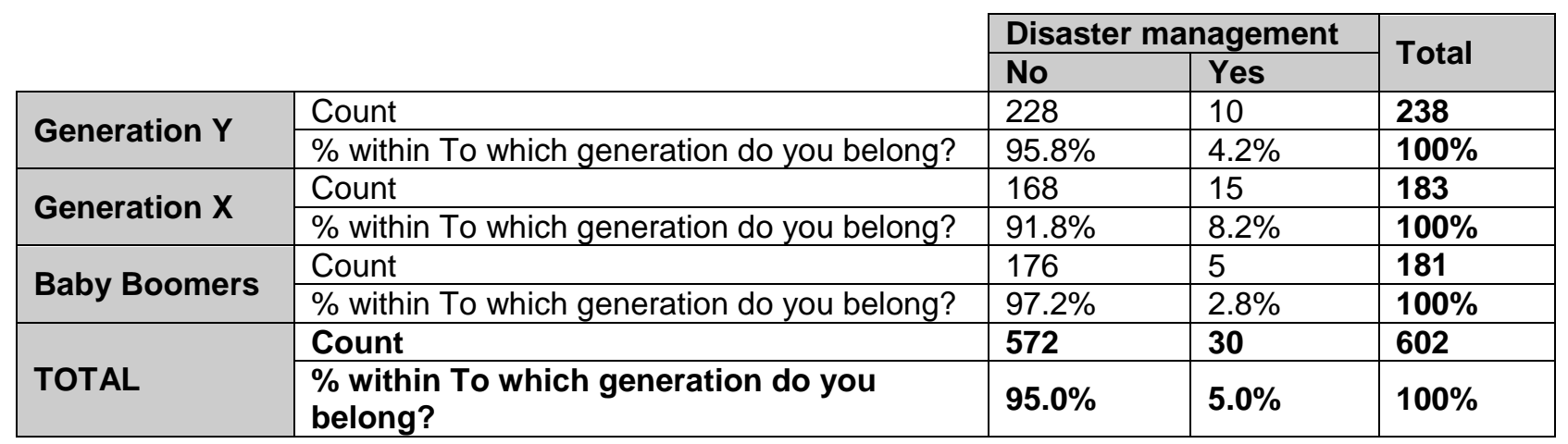

There is an association $\left(\mathrm{X}^{2}(1, \mathrm{n}=602)=6.183\right.$; small effect; Cramer's $\mathrm{V}=0.101$; $\mathrm{p}$-value $\left.=0.045\right)$ between the generations and supporting disaster management organisations. Generation $X$ is more likely to support disaster management organisations than Generation $Y$ and Baby Boomers.

Table 9: Generations supporting health-care organisations

\begin{tabular}{|c|c|c|c|c|}
\hline & \multicolumn{2}{|c|}{ Health care } & \multirow{2}{*}{ Total } \\
\hline & & No & Yes & \\
\hline \multirow{2}{*}{ Generation Y } & Count & 158 & 80 & 238 \\
\hline & $\%$ within To which generation do you belong? & $66.4 \%$ & $33.6 \%$ & $100 \%$ \\
\hline \multirow{2}{*}{ Generation X } & Count & 120 & 63 & 183 \\
\hline & $\%$ within To which generation do you belong? & $65.6 \%$ & $34.4 \%$ & $100 \%$ \\
\hline \multirow{2}{*}{ Baby Boomers } & Count & 139 & 42 & 181 \\
\hline & $\%$ within To which generation do you belong? & $76.8 \%$ & $23.2 \%$ & $100 \%$ \\
\hline \multirow[b]{2}{*}{ TOTAL } & Count & 417 & 185 & 602 \\
\hline & $\begin{array}{l}\% \text { within To which generation do you } \\
\text { belong? }\end{array}$ & $69.3 \%$ & $30.7 \%$ & $100 \%$ \\
\hline
\end{tabular}

There is an association $\left(x^{2}(1, n=602)=6.920\right.$; small effect; Cramer's $V=0.107$; $p$-value $\left.=0.031\right)$ between the generations and supporting health care organisations. Generation $X$ is more likely to support healthcare organisations than Generation $\mathrm{Y}$ and Baby Boomers. 
Table 10: Generations supporting religious organisations

\begin{tabular}{|c|c|c|c|c|}
\hline & \multicolumn{2}{|c|}{$\begin{array}{l}\text { Religious } \\
\text { organisations }\end{array}$} & \multirow[t]{2}{*}{ Total } \\
\hline & & No & Yes & \\
\hline \multirow{2}{*}{ Generation Y } & Count & 136 & 102 & 238 \\
\hline & $\%$ within To which generation do you belong? & $57.1 \%$ & $42.9 \%$ & $100 \%$ \\
\hline \multirow{2}{*}{ Generation X } & Count & 96 & 87 & 183 \\
\hline & $\%$ within To which generation do you belong? & $52.5 \%$ & $47.5 \%$ & $100 \%$ \\
\hline \multirow{2}{*}{ Baby Boomers } & Count & 81 & 100 & 181 \\
\hline & $\%$ within To which generation do you belong? & $44.8 \%$ & $55.2 \%$ & $100 \%$ \\
\hline \multirow[b]{2}{*}{ TOTAL } & Count & 313 & 289 & 602 \\
\hline & $\begin{array}{l}\% \text { within To which generation do you } \\
\text { belong? }\end{array}$ & $52.0 \%$ & $48.0 \%$ & $100 \%$ \\
\hline
\end{tabular}

There is an association $\left(\mathrm{X}^{2}(1, \mathrm{n}=602)=6.348\right.$; small effect; Cramer's $\mathrm{V}=0.103$; $\mathrm{p}$-value $\left.=0.042\right)$ between the generations and supporting religious organisations. Baby Boomers are more likely to support religious organisations than Generation $\mathrm{Y}$ and Generation X.

Based on the results, Hypothesis 3 is partially supported, since associations were uncovered between Generation $X$ and supporting disaster management and health-care organisations, and between Baby Boomers and supporting religious organisations.

\section{Hypothesis 4}

To test Hypothesis 4, the researchers made use of the one-way ANOVA test to determine whether significant differences exist between the levels of agreement that the different generations assign to their reasons for supporting NPOs. In all four instances reported here, the homogeneity of variance test indicated that equal variances can be assumed. Scheffe's post-hoc test was therefore used to flag the generations between which the significant differences exist. The following findings were apparent:

- There is a significant difference between the means of the generations when it comes to the statement 'I like giving something back to the community' ( $p$-value $=0.005)$. Scheffe's post-hoc test indicates that significant differences exist between Generation $Y$ (mean $=4.22$ ) and Generation $X$ (mean $=4.46)$, as well as between Generation $Y($ mean $=4.22$ ) and Baby Boomers (mean $=4.44)$.

- There is a significant difference between the means of the generations when it comes to the statement 'Due to the illness of a family member, friend or co-worker' $(p$-value $=0.003)$. Scheffe's post-hoc test indicates that significant differences exist between Generation $Y$ (mean $=2.39$ ) and Generation $X$ (mean $=2.82$ ), as well as between Generation $Y($ mean $=2.39$ ) and Baby Boomers (mean $=2.79)$.

- There is a significant difference between the means of the generations when it comes to the statement 'It is part of my organisation's corporate social responsibility initiative' ( $p$-value $=0.001$ ). Scheffe's post-hoc test indicates that significant differences exist between Generation $Y$ (mean = $2.40)$ and Generation $X($ mean $=2.88)$, and between Generation $Y($ mean $=2.40)$ and Baby Boomers (mean $=2.77$ ).

- There is a significant difference between the means of the generations when it comes to the statement 'Religious tradition' ( $p$-value $=0.019$ ). Scheffe's post-hoc test indicates that a significant difference exists between Generation $Y($ mean $=2.97)$ and Baby Boomers (mean $=3.34$ ).

Hypothesis 4 is therefore partially supported, since Generation $X$ and Baby Boomers are significantly more positive than Generation $Y$ about supporting NPOs as a means to give something back to the community; due to the illnesses of family, friends and co-workers, and as part of their organisation's corporate social responsibility. Baby Boomers are also significantly more positive than Generation $\mathrm{Y}$ about supporting NPOs as part of their religious tradition. Table 11 summarises the results of the hypotheses testing, whether they were accepted or rejected, as well as the main findings of each. 
Table 11: Summary of hypothesis testing

\begin{tabular}{|l|l|l|}
\hline Hypothesis & $\begin{array}{l}\text { Accepted } \\
\text { or rejected }\end{array}$ & Main finding \\
\hline $\begin{array}{l}\mathrm{H}_{1}: \text { There is an association } \\
\text { between the different generations } \\
\text { and their preferred methods of } \\
\text { supporting NPOs. }\end{array}$ & $\begin{array}{l}\text { Partially } \\
\text { accepted }\end{array}$ & $\begin{array}{l}\text { There are associations between Generation X and } \\
\text { supporting NPOs by donating money, as well as } \\
\text { between Generation Y and donating blood and } \\
\text { supporting NPOs by doing volunteer work. }\end{array}$ \\
\hline $\begin{array}{l}\mathrm{H}_{2}: \text { There is an association } \\
\text { between the different generations } \\
\text { and the frequency with which they } \\
\text { support NPOs. }\end{array}$ & $\begin{array}{l}\text { Partially } \\
\text { accepted }\end{array}$ & $\begin{array}{l}\text { There are associations between Generation Y and } \\
\text { supporting NPOs once a week and between Baby } \\
\text { Boomers and supporting NPOs once a month. }\end{array}$ \\
\hline $\begin{array}{l}\mathrm{H}_{3}: \text { There is an association } \\
\text { between the different generations } \\
\text { and the type of NPOs that they } \\
\text { prefer supporting. }\end{array}$ & Partially & accepted \\
\hline $\begin{array}{l}\mathrm{H}_{4}: \text { There is a significant } \\
\text { difference between the levels of } \\
\text { agreement that the different } \\
\text { generations assign to their } \\
\text { reasons for supporting NPOs. }\end{array}$ & $\begin{array}{l}\text { Associations were uncovered between Generation } \\
\text { X and supporting disaster management and } \\
\text { healthcare organisations, and between Baby } \\
\text { Boomers and supporting religious organisations. }\end{array}$ \\
\hline & accepted & $\begin{array}{l}\text { Generation X and Baby Boomers are significantly } \\
\text { more positive than Generation Y about supporting } \\
\text { NPOs as a means to give something back to the } \\
\text { community, due to the illnesses of family, friends } \\
\text { and co-workers, and as part of their organisation's } \\
\text { corporate social responsibility. Baby Boomers are } \\
\text { also significantly more positive than Generation Y } \\
\text { about supporting NPOs as part of their religious } \\
\text { tradition. }\end{array}$ \\
\hline
\end{tabular}

\section{MANAGERIAL IMPLICATIONS AND RECOMMENDATIONS}

NPOs are experiencing a decline in donations from Baby Boomers, which mean that they need to shift their focus to the younger generations, and thus develop marketing strategies to attract these as donors and volunteers (Schlegelmilch et al. 1997:24). In order to do so, it is important that NPOs have a better understanding of the donors' current supporting behaviour. Since there is little research available on this topic, this study sets out to uncover the differences between the generations in terms of the different methods in which they support NPOs, how frequently they support NPOs, the type of NPOs that they prefer supporting, and the reasons why they support NPOs.

Looking at the kind of support that the generations prefer giving, NPOs get an indication as to the type of support they can ask for in their communication strategies. Since there is tendency amongst the generations to prefer making monetary contributions, it is suggested that NPOs ask respondents to donate money.

In terms of the respondents' level of involvement with NPOs, the results reveal that the respondents are more inclined to get involved with NPOs at a low level through activities such as making small donations, and volunteering on an ad hoc basis. However, when asked how often they support NPOs, the respondents indicate a tendency to support NPOs on a monthly basis. This provides NPOs with the opportunity to ask donors to sign monthly debit order forms, thereby increasing their level of involvement with the organisation.

Knowing which types of NPOs the different generations prefer supporting, gives NPOs an indication as to who their target market is and consequently whom to approach and how to communicate with them. NPOs that take care of children can approach any one of the three generations as the respondents indicated a preference to support these types of NPOs. Even though this is the case, NPOs will need to 

profit organisations in Gauteng

decide on which generation they want to focus and accordingly put a strategy in place that will lead to the highest return for their investment made. Furthermore, the respondents are more likely to support the same NPO every time they provide support, thereby showing that they are loyal to the NPOs that they support. NPOs should therefore nurture the relationship they have with their donors if they want to receive future support from them.

Donors support NPOs for various reasons. Knowing the reasons that motivate donors to support NPOs, give NPOs an indication as to the approach that they should use when asking for support. Considering the results, it is suggested that when NPOs approach donors they should show how the support that they are receiving is helping their beneficiaries who are less fortunate. It is a message of hope. When an NPO's main target market is either Generation X and/or Baby Boomers, it is suggested that NPOs communicate how the support they are receiving is helping to uplift the community. Furthermore, Generation $Y$ and Baby Boomers have most probably experienced more illnesses of family, friends or co-workers and this could serve as motivation for them to support a particular NPO. This also provides NPOs with an opportunity to encourage them to not only support the NPO, but also the family member, friend or coworker in need. Generation X and Baby Boomers are also more inclined to support NPOs as part of their organisation's corporate social responsibility, which presents NPOs with a number of opportunities to partner with profit-driven organisations and get involved through cause-related marketing campaigns or volunteering initiatives. Baby Boomers furthermore see supporting NPOs as part of their religious tradition, which presents NPOs with further opportunities to partner with religious organisations.

When looking at the purpose of this paper, i.e. to obtain a better understanding of how the generations currently support NPOs, it is evident that the results give NPOs a good indication as to whom to approach when asking for support. The results furthermore reveal what type of support can be asked from whom, how frequently support can be asked for, and what drives people to support particular NPOs. Using this information, NPOs are able to compile a suitable marketing message that is aimed at the generation they want to target.

\section{CONCLUDING REMARKS}

In conclusion, NPOs are experiencing a decline in donations from their older donors and thus need to shift their efforts towards the younger generations. Consequently, NPOs have to obtain a better understanding of the supporting behaviour of the different generations under study in order to approach them more effectively. Based on the results obtained, it is evident that differences exist between the generations in terms of their supporting behaviour. As such, NPOs need to take these differences into account when approaching the different generations in search for their support.

\section{REFERENCES}

ANDREASEN AR \& KOTLER P. 2003. Strategic marketing for non-profit organisations. $6^{\text {th }}$ Edition. New Jersey: Prentice Hall.

BAKEWELL C \& MITCHELL VW. 2003. Generation Y female consumer decision-making styles. International Journal of Retail \& Distribution Management, 31(2):95-106.

BLACKWELL RD, MINIARD PW \& ENGEL JF. 2006. Consumer Behavior. 10 $0^{\text {th }}$ Edition. Mason: Thomson South-Western.

BRIGGS E, LANDRY T \& WOOD C. 2007. Beyond just being there: an examination of the impact of attitudes, materialism, and self-esteem on the quality of helping behaviour in youth volunteers. Journal of Nonprofit and Public Sector Marketing, 18(2):27-45. 
BURNS DJ, REID J, TONCAR M, ANDERSON C \& WELLS C. 2008. The effect of gender on the motivation of members of Generation $Y$ college students to volunteer. Journal of Nonprofit \& Public Sector Marketing, 19(1):99-118.

CLOHESY WW. 2003. Fund-raising and the articulation of common goods. Nonprofit and Voluntary Sector Quarterly, 32(1):128-140.

CODRINGTON G \& GRANT-MARSHALL S. 2005. Mind the gap! South Africa: Penguin Books.

CONE INCORPORATED. 2006. The 2006 Cone Millennial Cause Study: The Millenial generation - Prosocial and empowerment to change the world. [Internet: http://www.coneinc.com/stuff/contentmgr/files/0/b45715685e62ca5c6ceb3e5a09f25bba/files/2006_cone_ millennial_cause_study_white_paper.pdf; downloaded on 2009-11-10.]

DEPARTMENT OF SOCIAL DEVELOPMENT. 2008. All you need to know about the registration of a NonProfit Organisation (NPO). [Internet: http://www.dsd.gov.za/npo/index.php?option=com_content\&task=view\&id=66\&ltemid=114; downloaded on 2010-04-03.]

DEPARTMENT OF SOCIAL DEVELOPMENT. 2010. Database search menu. [Internet: http://www.npo.gov.za/frmSNOrg.aspx downloaded on 2010-04-03.]

EISELEN R, UYS T \& POTGIETER T. 2007. Analysing Survey Data using SPSS13. 3 Edition. Statkon: University of Johannesburg.

GLADDEN JM, MAHONY DF \& APOSTOLOPOULOU A. 2005. Toward a better understanding of college athletic donors: what are the primary motives? Sport Marketing Quarterly, 14(1):18-30.

HAWKINS DI \& MOTHERSBAUGH DL. 2010. Consumer behavior: building marketing strategy. $11^{\text {th }}$ Edition. New York: McGraw-Hill/Irwin.

HIBBERT S \& HORNE S. 1996. Giving to charity: questioning the donor decision process. Journal of Consumer Marketing, 13(2):4-13.

HOYER WD \& MACINNIS DJ. 2010. Consumer behaviour, 5th Edition. USA: South-Western Cengage Learning.

KOTTASZ R. 2004. How should charitable organisations motivate young professionals to give philanthropically? International Journal of Nonprofit and Voluntary Sector Marketing, 9(1):9-27.

LAMB CW, HAIR JF, MCDANIEL C, BOSHOFF C \& TERBLANCHE NS. 2008. Marketing. $3^{\text {rd }}$ Edition. Cape Town: Oxford University Press.

LEMMENS KPH, ABRAHAM C, RUITER RAC, VELDHUIZEN IJT, DEHING CJG, BOS AER \& SCHAALMA HP. 2009. Modelling antecedents of blood donation motivation among non-donors of varying age and education. British Journal of Psychology, 100:71-90.

MACCHIETTE B \& ROY A. 2001. Taking sides: Clashing views on controversial issues in marketing. USA: McGraw-Hill/Dushkin.

MAGSON N \& ROUTLEY C. 2009. Using data in legacy fundraising: a practical approach. International Journal of Nonprofit and Voluntary Sector Marketing, 14:333-340. 


\section{L du Plessis \\ DJ Petzer}

\section{The supporting behaviour of generations towards non- profit organisations in Gauteng}

MALHOTRA NK. 2007. Marketing research: an applied orientation. $5^{\text {th }}$ Edition. New Jersey: Pearson Prentice Hall.

MI J \& NESTA F. 2006. Marketing library services to the Net generation. Library Management, 27(6/7):411-422.

NICHOLS JE. 2004. Repositioning fundraising in the $21^{\text {st }}$ century. International Journal of Nonprofit and Voluntary Sector Marketing, 9(2):163-170.

RANGANATHAN SK \& HENLEY WH. 2008. Determinants of charitable donation intentions: a structural equation model. International Journal of Nonprofit and Voluntary Sector Marketing, 13:1-11.

REISENWITZ TH \& IYER R. 2009. Differences in Generation X and Generation Y: implications for the organisation and marketers. Marketing Management Journal, 19(2):91-103.

RIECKEN G \& YAVAS U. 2005. The attitudes of donors and non-donors to the march of dimes charity in the United States: a case study in non-profit marketing. International Journal of Management, 22(4):572581.

SOUTHERN AFRICA INSTITUTE OF FUNDRAISING. 2009. Glossary of fundraising terms. [Internet: http://www.saifundraising.org.za/glossary.htm\#D; downloaded on 2010-04-05.]

SCHLEGELMILCH BB, DIAMANTOPOULOS A \& LOVE A. 1997. Characteristics affecting charitable donations: empirical evidence from Britain. Journal of Marketing Practice: Applied Marketing Science, $3(1): 14-28$.

SOUTH AFRICAN REVENUE SERVICE. 2007. Tax exemption guide for public benefit organisations in South Africa. [Internet: http://www.sars.co.za/home.asp?pid=170; downloaded on 2010-04-03.]

THORNTON J. 2006. Nonprofit fund-raising in competitive donor markets. Nonprofit and Voluntary Sector Quarterly, 35(2):204-224.

TSCHIRHART M, MESCH DJ, PERRY JL, MILLER TK \& LEE G. 2001. Stipend volunteers: their goals, experiences, satisfaction and likelihood of future service. Nonprofit and Voluntary Sector Quarterly, $30(3): 422-443$.

WEBB DJ, GREEN CL \& BRASHEAR TG. 2000. Development and validation of scales to measure attitudes influencing monetary donations to charitable organisations. Journal of the Academy of Marketing Science, 28(2):299-309.

WILSON A \& PIMM G. 1996. The tyranny of the volunteer: the care and feeding of voluntary workforces. Management Decisions, 34(4):24-40. 